\title{
TRADUÇÃ O \\ COMUNITÁRIA \\ EM TEMPOS DE PANDEMIA \\ COMO PROMOTORA \\ DA EDUCAÇÃO \\ LINGUÍSTICA
}

\section{TRADUCCIÓN COMUNITARIA EN TIEMPOS DE PANDEMIA Y PROMOCIÓN DE LA EDUCACIÓN LINGÜÍSTICA}

\author{
COMMUNITY TRANSLATION IN PANDEMIC TIMES AS A PROMOTER OF LINGUISTIC \\ EDUCATION
}

\begin{abstract}
Andrea Cristiane Kahmann*
Universidade Federal de Pelotas
\end{abstract}

Elisa Marchioro Stumpf**

Universidade Federal do Rio Grande do Sul

Bernardo Kolling Limberger***

Universidade Federal de Pelotas

RESUMO: O projeto “Tradução, mediação linguística e disseminação de informações à comunidade”, desenvolvido entre março e dezembro de 2020 na Universidade Federal de Pelotas, teve como objetivo principal disseminar informações confiáveis e precisas à comunidade durante a pandemia. A equipe pesquisou conteúdos de relevância social e divulgou textos para disseminar informações à comunidade e, de forma paralela, permitiu o desenvolvimento de diferentes habilidades. Neste artigo, discutem-se as contribuições do projeto para a educação linguística de participantes, a partir de resultados obtidos por meio de questionário enviado a integrantes. Os resultados mostram diferentes percepções sobre as contribuições à educação linguística: melhora na leitura e escrita em português e no conhecimento de outras línguas, além do desenvolvimento de letramentos acadêmicos e/ou informacionais. Embora

\footnotetext{
* Doutora em Letras - Estudos de Literatura - pela Universidade Federal do Rio Grande do Sul. Professora dos Bacharelados em Letras - Tradução e Programa de Pós-Graduação em Letras da Universidade Federal de Pelotas. E-mail: ackahmann@gmail.com.

** Doutora em Letras - Estudos da Linguagem - pela Universidade Federal do Rio Grande do Sul. Professora do Departamentode Línguas Modernas da Universidade Federaldo Rio Grandedo Sul. E-mail: elisa.stumpf@gmail.com.

*** Doutor em Letras (Linguística) pela Pontifícia Universidade Católica do Rio Grande do Sul. Professor da área de Alemão e do Programa de Pós-Graduação em Letras na Universidade Federal de Pelotas. E-mail: limberger.bernardo@gmail.com.
} 
o objetivo do projeto não tenha sido a educação linguística, as percepções sugerem, entre outras, a efetiva contribuição da tradução para aprendizagem de línguas e sensibilização para o multilinguismo.

PALAVRAS-CHAVE: Tradução comunitária. Educação linguística. Pandemia de covid-19.

RESUMEN: El proyecto "Tradução, mediação linguística e disseminação de informações à comunidade" [Traducción, mediación lingüística y diseminación de información a la comunidad] ha sido desarrollado en la Universidad Federal de Pelotas (UFPel) entre marzo y diciembre de 2020. Buscando ofrecer informaciones precisas y confiables durante la pandemia, han sido seleccionados, traducidos y diseminados a la comunidad contenidos científicos de relevancia social. Paralelamente, se ha observado el desarrollo de diferentes habilidades lingüísticas entre los estudiantes participantes. Eso es lo que discute este artículo a partir de las respuestas a un cuestionario elaborado por la supervisión del equipo. Los resultados demuestran las siguientes percepciones respecto a la educación lingǘstica: mejora en la lectura y escritura en portugués y de conocimiento de otras lenguas y desarrollo de la literacidad academica e/o informacional. Aunque la educación lingüística no haya sido el objetivo de dicho proyecto, las percepciones de sus participantes sugieren, entre otros aspectos, una efectiva contribución de actividades de traducción hacia el aprendizaje de idiomas y la sensibilización al multilingüismo.

PALABRAS CLAVE: Traducción comunitaria. Educación lingüística. Pandemia de Covid-19.

ABSTRACT: The project "Tradução, mediação linguística e disseminação de informações à comunidade" [Translation, linguistic mediation and diffusion of information to the community], developed at the Federal University of Pelotas (Brazil) in 2020 (from March to December), aimed at spreading accurate and reliable information during the covid-19 pandemic. A team of volunteers looked for texts with potential social impact and circulated them to keep the community informed and, in parallel, developed different skills. This study discusses how this community translation project contributed to the participants' linguistic education, drawing on a questionnaire sent out to participants. Results show different perceptions about the contributions of the project: improvement of reading and writing skills in Portuguese and also increased knowledge in other languages, besides the development of academic and/or informational literacies. Although linguistic education was not the main goal of the project, participants' perceptions suggest the effective contribution of translation to language learning and awareness of multilingualism, among other benefits.

KEYWORDS: Community translation. Linguistic education. Covid-19 pandemic.

\section{INTRODUÇ̃̃O}

A interação permanente entre estudos teóricos e estudos empíricos é a base de toda a disciplina. Afinal, a ciência começa com a observação sistematizada de fatos que podem permitir conclusões generalizantes quando, repetidas vezes, apontam para os mesmos resultados. É sob essa perspectiva, e visando a possibilitar reflexões posteriores, que este artigo apresenta o caso do projeto unificado de extensão, ensino e pesquisa "Tradução, mediação linguística e disseminação de informações à comunidade", proposto em março de 2020 e desenvolvido até o final desse ano, na Universidade Federal de Pelotas (UFPel) com o apoio de outras instituições. A propositura desse projeto foi motivada pela pandemia da covid-19, que chegou ao Brasil em março de 2020. Juntamente com a crise da saúde, intensificou-se o espalhamento de desinformação, com fortes contornos políticos, possibilitado pelas redes sociais como Facebook, Twitter e WhatsApp, o que agravou a pandemia. Por desinformação, entendemos diversos tipos de conteúdo, desde a veiculação de algum conteúdo com base na realidade, mas que se apresenta de forma distorcida, até mesmo conteúdo completamente fabricado, mas sempre com o propósito de enganar interlocutores (SOARES et al., 2020; RECUERO; SOARES; ZAGO, 2020).

Neste contexto, reuniu-se um grupo de docentes da área de Letras e estudantes de diversos cursos a fim de preservarem-se os vínculos com a universidade por meio da oferta de atividades complementares não obrigatórias (tendo em vista a suspensão das aulas presenciais) e, ao mesmo tempo, contribuir com a comunidade por meio da tradução comunitária ${ }^{1}$. Com a finalização do

${ }^{1}$ Tem-se usado o termo "tradução comunitária" (empregando-se o termo tradução em sentido mais abrangente) ou "interpretação comunitária" (no sentido de tradução oral, haja vista que essa é a modalidade mais frequente nesse campo de atuação) ou simplesmente "tradução / interpretação social" ou "tradução / interpretação para a comunidade" para qualquer tipo de tradução / interpretação "dirigida a um cliente e um prestador de serviços dentro de contexto hospitalar, 
projeto em dezembro de 2020, foram tecidas reflexões a respeito do seu funcionamento e, mais especificamente, sobre como funcionou enquanto instância promotora da educação linguística. Entende-se por educação linguística o conjunto de fatores socioculturais que possibilitam adquirir, desenvolver e ampliar o conhecimento linguístico e semiótico para o exercício da cidadania (BAGNO; RANGEL, 2005). De fato, para Cope e Kalantzis (2000, p. 6), "[...] a efetiva cidadania e o trabalho produtivo atualmente requerem interação efetiva usando múltiplas línguas/linguagens [...] e padrões de comunicação que frequentemente cruzam fronteiras culturais, comunitárias e nacionais" ${ }^{2}$.

Dessa forma, o objetivo deste estudo é discutir a contribuição do projeto de tradução comunitária na educação linguística de estudantes que dele participaram. Para isso, inicia-se com uma apresentação do projeto e do seu funcionamento, para depois explicar a metodologia deste trabalho e analisar em que medida o projeto contribuiu para a educação linguística de participantes. Por fim, discutem-se as limitações deste tipo de iniciativa e indicam-se possibilidades futuras. Busca-se, deste modo, contribuir para o desenvolvimento de novas reflexões, embora, como é da limitação do método, este trabalho não persiga a verdade, mas indique hipóteses a serem confirmadas em pesquisas futuras.

\section{PROJETO TRADUÇÃO, MEDIAÇÃO LINGUÍSTICA E DISSEMINAÇÃO DE INFORMAÇÕES À COMUNIDADE: CONCEPÇÃO E DESCRIÇÃO}

Em dezembro de 2019, os primeiros casos do que parecia ser uma nova doença viral foram identificados na cidade chinesa de Wuhan. O alto potencial letal do SARS-CoV-2, o vírus causador da doença que ficou conhecida como covid-19, por ser a doença provocada pelo coronavírus (Corona Virus Disease) identificado em 2019, levou a Organização Mundial da Saúde a decretar emergência de saúde pública de importância internacional em 30 de janeiro de 2020 e estado de pandemia no dia 11 de março de 2020. Em todo o mundo, foram implementadas medidas de controle de circulação de pessoas visando a conter a propagação do novo vírus, enquanto a ciência buscava compreendê-lo e neutralizar seu rápido contágio por meio de uma vacina.

A Universidade Federal de Pelotas (UFPel) já havia constituído um comitê interno para acompanhamento da evolução da pandemia por coronavírus, e esse, em reunião ocorrida na manhã de 13 de março de 2020 (a primeira sexta-feira da semana que dera início ao calendário acadêmico de 2020), divulgou nota suspendendo as atividades acadêmicas por um período mínimo de três semanas. Essa suspensão foi prorrogada sucessivamente até que um calendário acadêmico alternativo, inteiramente remoto, tivesse início em junho de 2020. O mesmo comitê, que passou a ser designado apenas como Comitê UFPel COVID-19, passou a divulgar boletins diários, primeiramente voltados apenas à comunidade acadêmica (contendo recomendações como, por exemplo, protocolos de higiene de mãos e distanciamento físico para acesso ao Restaurante Universitário, e imposições como a suspensão imediata de formaturas, contidas no boletim de 16 de março de 2020). Posteriormente, o Comitê divulgou informações de interesse comunitário (como as informações sobre como colocar, usar, retirar e descartar uma máscara, publicado no boletim diário nº 30 , de 28 de abril de 2020). Quem acompanhasse diariamente as informações do Comitê por meio de redes sociais ou pelos boletins perceberia esforços progressivos de democratização da linguagem, tornando-a mais clara à comunidade geral. Se, em 13 de março, foi divulgada apenas a recomendação de "usar etiqueta respiratória" ao espirrar, no boletim no 2, de 17 de março, já se lia: "adotar as medidas de 'etiqueta respiratória' (ao tossir ou espirrar, cobrir o nariz e a boca com lenço ou o braço e não com as mãos)” e, depois, em 23 de março, que "em caso de tosse, cobrir a boca com o antebraço, nunca usando as mãos" (UFPEL, 2020).

\footnotetext{
forense, judiciário e similares. Serve àqueles que vêm de outros países, imigrantes ou os que buscam asilo político como refugiados, a se comunicarem e acessarem os serviços educacionais, judiciários e médicos daquele país em que residem agora, mas não sendo fluentes na língua, necessitam da ajuda de um intérprete" (ORIGUELA, 2014, p. 226). Essa conceituação tem sido ampliada para abarcar comunidades internas à nação, mas que não são usuárias da língua hegemônica, como ocorre com as comunidades surdas, ou com comunidades que, embora conheçam a língua hegemônica, não sejam proficientes ou possam apresentar dificuldades linguísticas e culturais para o efetivo exercício da cidadania, como ocorre com os povos originários e comunidades que tenham línguas de migração como primeira língua.

${ }^{2}$ No original: "Effective citizenship and productive work now require that we interact effectively using multiple languages, multiple Englishes, and communication patterns that more frequently cross cultural, community, and national boundaries” (COPE; KALANTZIS, 2000, p. 6). Tradução nossa.
} 
Contudo, na primeira fase da pandemia, o epicentro da nova doença ainda se concentrava em países europeus, o que demandava esforços de tradução, sobretudo interlingual ${ }^{3}$. Assim, docentes de diferentes línguas (português como língua de acolhimento, inglês, espanhol, francês, alemão e libras) e diferentes cursos de Letras (licenciaturas e bacharelados em tradução) uniram-se para conceber um projeto unificado de ensino, pesquisa e extensão, que restou intitulado como "Tradução, mediação linguística e disseminação de informações à comunidade", que foi cadastrado em 27 de março e iniciou execução três dias depois. Esse projeto buscava, primeiramente, acolher aos apelos da Pró-Reitoria de Ensino, direcionados a colegiados de cursos de graduação e reiterados por meio do Memorando-Circular $n^{\circ}$ 8/2020, de 26 de março, para que fossem previstas atividades complementares não obrigatórias correlatas às diretrizes pedagógicas dos cursos, a fim de manter interação entre docentes e discentes e evitar os prejuízos da suspensão de atividades letivas presenciais. No entanto, conforme a iniciativa foi sendo divulgada em redes sociais, acabou por extrapolar em muito o âmbito do Centro de Letras e Comunicação e inclusive da universidade. Não tardou a que se recebesse o apoio generoso do grupo Mobilang (2021), que já contava com ampla experiência em pesquisa e formação de mediadoras e mediadores linguísticos. O grupo Mobilang tem como objetivo observar as práticas e os fenômenos de contatos linguísticos decorrentes das mobilidades humanas, bem como de mapear o multilinguismo e as políticas linguísticas em favor do multilinguismo. Com o advento de uma pandemia sem precedentes como a da covid-19, por certo, a disseminação de informações confiáveis para a proteção da vida passou a ser demanda premente e, dessa forma, os contatos foram estabelecidos a fim de reunir esforços visando à tradução comunitária.

A propositura deste projeto estava em consonância com a Política Linguística da Universidade, que tem como um dos princípios “a promoção do acesso plurilíngue ao conhecimento e a difusão das produções acadêmicas e institucionais da UFPel em diferentes línguas" (UFPEL, 2020, p. 2). Além da promoção pela universidade de conhecimento em libras e outras línguas (especialmente inglês), entende-se que projetos como este devam ser priorizados, pois estão de acordo com o princípio referido em função de (1) possibilitarem à comunidade geral acesso a conhecimentos e conteúdos produzidos em outras línguas (em maior parte anglófonos, mas também francófonos, germanófonos e hispanófonos) e (2) possibilitarem acesso ao conhecimento em outras línguas para migrantes no Brasil (especialmente hispânicos). Portanto, o projeto estava de acordo com uma política que favorecia o uso do multilinguismo no âmbito universitário, o que se concretizou por meio da tradução, ou seja, do uso de línguas adicionais com foco na democratização de informações à comunidade. Dessa forma, a universidade desempenhou um relevante papel de agência na gestão linguística (SPOLSKY, 2009), por exemplo, por meio do trabalho para resolver dificuldades de comunicação na mudança de língua.

Com o apoio do grupo Mobilang e de outras instâncias, inclusive da própria comunidade acadêmica da UFPel, o projeto "Tradução, mediação linguística e disseminação de informações à comunidade" (2020) passou a ofertar traduções à comunidade. O públicoalvo do projeto eram organizações governamentais ou não governamentais, instituições públicas ou de interesse público, especialmente profissionais da saúde, da justiça, da assistência social, do desenvolvimento e da cultura, ou pessoas dedicadas a pesquisas com o objetivo de promover e disseminar produtos e conhecimentos para a proteção da vida e demais direitos fundamentais. Atendendo a esse objetivo, foi realizada, entre outros trabalhos, uma versão para espanhol, voltada à comunidade imigrante, de cartilha sobre auxílio emergencial, demanda recebida por meio do projeto "O Direito de olho do social", da UFPel. Também houve colaboração com a validação de termos relacionados à covid-19 para a inclusão do português brasileiro no glossário multilíngue de consulta aberta no site da ONG Translators Without Borders (2020) [Tradutores sem fronteiras]. Essa instituição, que é a maior do mundo a oferecer serviços de tradução pro bono, apresenta-se como já tendo traduzido 83.319 .490 palavras como forma de apoio a causas humanitárias em escala global, prestando assistência linguística a organizações como Médicos sem Fronteiras, Médicos do Mundo, Handicap International, entre muitas outras.

Contudo, para além desse primeiro objetivo, o grupo da UFPel também propôs pesquisar conteúdos de áreas sensíveis, como saúde (tais como protocolos e artigos científicos para combate a epidemias/pandemias e conteúdos correlatos), justiça, desenvolvimento econômico-social sustentável não excludente, bem como tecnologias de inclusão e cultura publicados em línguas estrangeiras

${ }^{3}$ Tradução Interlingual (ou tradução propriamente dita) é a "interpretação dos signos verbais por meio de alguma outra língua”, segundo conceito de Jakobson (1991[1959], p. 65). 
visando à disseminação desses conhecimentos por meio da tradução interlingual, intralingual ou intersemiótica ${ }^{4}$, segundo os tipos de tradução propostos por Jakobson ([1959] 1991, p. 65). Foi nessa ação que se centrou a atuação da maior parte do voluntariado deste projeto e sobre a qual repousam as reflexões que passamos a apresentar.

\section{A TRADUÇÃO PARA DEMOCRATIZAÇÃO DE INFORMAÇÕES CONFIÁVEIS À COMUNIDADE}

A equipe do projeto “Tradução, mediação linguística e disseminação de informações à comunidade" recebeu, entre 26 e 31 de março de 2020, 83 inscrições de pessoas com diferentes backgrounds de formação, áreas acadêmicas, idades e até mesmo nacionalidades. Falantes de diferentes línguas que se voluntariaram a atuar neste projeto tinham como desafio comum a pesquisa de conteúdos sensíveis à comunidade, notadamente conteúdos das áreas de saúde, em função do contexto de emergência sanitária que, então, recém principiava. É possível afirmar que a totalidade da equipe tinha como característica (1) o domínio de, ao menos, uma segunda língua, (2) disponibilidade ou intenção de contribuir com tarefas de tradução e mediação linguística, ainda que desde a perspectiva de outras áreas de formação, (3) acesso a tecnologias da informação e (4) disponibilidade ou intenção para realizar pesquisa, seleção, leitura e reformulação de conteúdos confiáveis em áreas sensíveis à comunidade veiculados em língua diferente do português. Nesses termos, para além da tradução interlingual (entre diferentes idiomas), demandou-se à equipe atividades em tradução intralingual (dentro do mesmo idioma) a fim de disseminar informações em redes sociais e, consequentemente, promover a democratização de conhecimentos em tese e a princípio inacessíveis ao público amplo, seja pela produção em língua estrangeira, seja pelas características do texto científico que visa a seus próprios pares. Dito de outro modo, tratou-se de uma atividade de acessibilidade textual e terminológica, além, é claro, da curadoria de conteúdos para difusão.

A fim de viabilizar essas tarefas, foram enviados e-mails às pessoas inscritas no projeto com instruções para orientar a pesquisa de conteúdos científicos e a elaboração de textos a serem divulgados no perfil do projeto em rede social. Depois de algumas semanas com o projeto em curso, constatou-se, por meio das ferramentas disponíveis nas redes sociais, que as postagens mais visualizadas e compartilhadas eram as que continham textos curtos e diretos. Desse modo, foi proposto o modelo constante no Anexo 1. Uma das voluntárias do projeto, porém, aluna do curso de Cinema e Audiovisual da Universidade, disponibilizou-se a trabalhar com imagens. Além de produzir ilustrações que pudessem se relacionar com os conteúdos científicos a serem divulgados, propôs elaborar ao final de cada semana um quadro, por ela intitulado de "A semana explicada", em que resumia as principais descobertas científicas divulgadas na semana que findava. Esse quadro-síntese, sempre elaborado com cores fortes e contrastantes, acabou por constituir o principal produto do projeto, pois produzido com periodicidade definida e apresentando de forma clara e objetiva os progressos da ciência a cada semana. Além dessa participante, também uma aluna de Letras propôs alguns trabalhos com imagens, mais voltados para o humor, ao estilo dos memes de internet. Um deles foi elaborado sobre fotografia de um dos cachorros mais queridos do campus onde se situa o curso de Letras. Inserindo o desenho de uma máscara sobre o focinho do cachorro, escreveu, embaixo da fotografia, em letras grandes e amarelas: "usem máscara, aumigues!" Apesar de terem sido esses trabalhos com imagens os mais curtidos e compartilhados nas redes do projeto, foi na divulgação de informações conforme o modelo do Anexo 1 que se concentrou a maior parte da equipe.

\section{O PROJETO COMO PROMOTOR DE EDUCAÇÃO LINGUÍSTICA NO ENSINO SUPERIOR}

Considerando as atividades desenvolvidas, percebe-se que as línguas e a capacidade de mediação de conhecimento em diferentes idiomas foi o elemento central do projeto, segundo a ótica das pessoas aceitaram participar da pesquisa formulada. Dessa forma, é de supor que uma das suas principais contribuições foi a promoção da educação linguística de participantes que, reunindo-se pela vontade de trocar conhecimentos sobre a pandemia, tiveram oportunidades significativas para participar de práticas colaborativas de aprendizagem de e sobre línguas e comunicação. Para Bagno e Rangel (2005, p. 63), a educação linguística é compreendida como

\footnotetext{
${ }^{4}$ Tradução Interlingual (ou tradução propriamente dita) é a "interpretação dos signos verbais por meio de alguma outra língua”, segundo conceito de Jakobson ([1959] 1991, p. 65), que a difere de outros dois tipos de tradução: a intralingual (ou reformulação), que consiste na "interpretação dos signos verbais por meio de outros signos da mesma língua" (JAKOBSON, [1959] 1991, p. 64) e a intersemiótica, "ou transmutação dos signos verbais por meio de sistemas de signos não-verbais" (JAKOBSON, 1991 [1959], p. 65).
} 
"[...] o conjunto de fatores socioculturais que, durante toda a existência de um indivíduo, lhe possibilitam adquirir, desenvolver e ampliar o conhecimento de/sobre sua língua materna, de/sobre outras línguas, sobre a linguagem de um modo mais geral e sobre todos os demais sistemas semióticos”.

Ainda que muitos trabalhos na área destaquem sua importância na educação básica, a proposta dos autores deixa claro que a educação linguística é um processo contínuo, que pode se estender por outras etapas de escolarização, bem como pode se dar, também, fora das instituições de educação formal.

Com relação a esse ponto, cabe questionar o espaço concedido à educação linguística no ensino superior. Se ela parece ser uma tarefa óbvia dos cursos de Letras, seu lugar e sua importância são dificilmente reconhecidos quando se trata de outros cursos, embora seja comum o lamento sobre uma crescente falta de domínio da variedade acadêmica da língua portuguesa e as dificuldades na interpretação e produção de textos por parte de estudantes. Além disso, as dificuldades na compreensão e produção de textos em língua estrangeira, notadamente o inglês, são uma crescente demanda devido à necessidade de internacionalização. Muitas vezes, a solução apresentada se restringe à oferta de cursos básicos de português, geralmente ministrados nos primeiros semestres, e comumente intitulados de "português instrumental" ou "leitura e escrita para fins acadêmicos", dentre outros, cujo conteúdo pode ser tão variado quanto seu nome. Subjaz a isso uma noção de que as tais dificuldades encontradas na passagem do ensino médio ao ensino superior possam ser resolvidas ou satisfatoriamente sanadas com cerca de 60 horas de ensino em turmas que misturam diferentes cursos e tradições disciplinares.

Tal perspectiva do déficit já foi há muito questionada por pessoas dedicadas à pesquisa nas áreas de leitura e escrita que enfatizam os aspectos sociais de tais práticas (LEA, 2004; LEA; STREET, 2006). Assim, no que diz respeito a essas habilidades, a chegada ao ensino superior envolve não só o domínio de um novo vocabulário próprio de cada área do conhecimento, mas, também, novas formas de dizer, ou seja, gêneros discursivos específicos da esfera acadêmica e recursos semióticos que são comumente utilizados em tais textos (RUSSEL, 2009).

O fato de que cada área do conhecimento tenha suas formas de dizer próprias, que devem ser apreendidas a par com o desenvolvimento de competências ao longo do curso, significa que uma disciplina no estágio inicial de formação e com a participação de diversos cursos dificilmente vai dar conta das necessidades de ingressantes na graduação. No máximo, é possível tratar de questões relativas ao domínio da norma-padrão e introduzir alguns gêneros comuns no universo acadêmico. Isso, porém, é feito sem atentar para variações disciplinares, além da apresentação das normas que regem a formatação de trabalhos acadêmicos, cujo domínio, muitas vezes, passa a simbolizar a apropriação do discurso acadêmico. Nesse contexto, é possível supor que, conforme as diretrizes brasileiras a orientar os cursos de graduação, estudantes tenham poucas oportunidades formais de educação linguística ao longo da sua trajetória universitária, tanto na língua materna quanto em línguas adicionais.

Outra tarefa da educação linguística, conforme apontada por Bagno e Rangel (2005), seria a conscientização a respeito da diversidade linguística vivenciada no Brasil. Apesar de grandes esforços empreendidos na construção da imagem de um país monolíngue, estão presentes, ainda hoje, no território brasileiro, centenas de línguas, que contribuem para a complexificação das nossas identidades ${ }^{5}$ plurais.

\footnotetext{
${ }^{5}$ No que tange a populações indígenas, o Instituto Brasileiro de Geografia e Estatística (IBGE), seguindo parâmetros internacionais, usa três critérios para classificálas como tal: a "investigação da etnia, da língua falada no domicílio e da localização geográfica" (IBGE, 2012, p. 18, o grifo é nosso). Conforme o Censo de 2010, $17,5 \%$ do total da população indígena não falava o português, percentual que aumentava para $28,8 \%$, quando restrito à população de terras indígenas.
} 
Para a conformação da babel brasileira, como refere Lia Wyler (2003, p. 32), contribuíram as línguas orais e de sinais dos povos originários $^{6} \mathrm{e}$ as do processo de colonização / conquista europeia, além das línguas africanas ${ }^{7}$. Esse multilinguismo põe em destaque a imprescindibilidade da tradução como elemento de mediação cultural, pois é possível afirmar que, desde o século XVI, houve no Brasil “[...] um extraordinário número de línguas em confronto, o que exigiu a presença de mediadores - as línguas ou intérpretes para que a comunicação pudesse efetivamente acontecer" (WYLER, 2003, p. 34).

Nos séculos XIX e XX, acresceram-se a esse contexto multilíngue outras línguas de imigração, como as alemãs e italianas, e, ainda mais recentemente, somaram-se línguas outras, tais como o árabe, o crioulo haitiano e o wolof ${ }^{8}$, além de um regresso da língua espanhola ao centro da relevância, trazida sobretudo da Venezuela, junto com o warao ${ }^{9}$. Conforme o Alto Comissariado das Nações Unidas para Refugiados (ACNUR), a nacionalidade com maior número de pessoas em situação de refúgio reconhecida no Brasil, entre 2011 e 2019, era a venezuelana, seguida da síria e da congolesa. Em 2019, porém, pessoas provenientes do Haiti representaram 20,1\% das solicitações de refúgio no Brasil. Esse panorama linguístico foi complexificado ante a triste realidade que, no ano de 2019 , ou seja, ainda antes da crise provocada pela pandemia, apontava que 1\% da população mundial encontrava-se em situação de migração forçada (ACNUR, 2020). É possível que esse quadro se tenha acentuado ainda mais em face da crise desencadeada pela covid-19. Como alerta Boaventura de Sousa Santos (2020), crises como a atual tendem a vulnerabilizar ainda mais os grupos sociais mais vulneráveis: pessoas obrigadas a trabalhos precários e de rua, sem-teto ou habitantes de periferias sem habitação adequada e sem acesso a saneamento básico e a serviços públicos, especialmente as mulheres (pois socialmente incumbidas da prestação de cuidados dentro e fora das famílias e mais sujeitas a violências diversas) e as pessoas idosas ou com deficiência. Por certo, essas pessoas, quando integrantes de comunidades internadas em campos de refúgio ou indocumentadas ou deslocadas internamente estão ainda mais expostas à cruel pedagogia do vírus (SANTOS, 2020).

Na região de Pelotas, e no Rio Grande do Sul de modo geral, ainda não há (ou não parece haver) o devido reconhecimento da variedade linguística local. Embora sejam gaúchos 12 dos 14 municípios que cooficializaram o talian como língua de imigração italiana, conforme levantamento do Instituto de Investigação e Desenvolvimento em Política Linguística (IPOL, 2021) ${ }^{10}$, não recebem o mesmo reconhecimento as demais línguas existentes no Estado, ainda que de imigração recente. Apesar disso, é preciso recordar com Maria Stella Ferreira Levy, em seu estudo, de 1974, baseado em censos populacionais, que:

\footnotetext{
${ }^{6}$ Conforme dados obtidos no Censo de 2010 pelo Instituto Brasileiro de Geografia e Estatística (IBGE), seriam 274 as línguas indígenas existentes no território nacional por indivíduos pertencentes a 305 etnias diferentes. Na tabela apresentada pelo IBGE, encontra-se, além de línguas orais, a língua de sinais ka' apor. Essas 274 línguas conformam apenas uma pequena parte das "centenas de línguas e dialetos, que contemporaneamente podem ser classificados em 102 grupos e três ramos linguísticos: o tupi, o macro-gê e o aruaque” (WYLER, 2003, p. 31), existentes no século XV.
}

${ }^{7}$ Lia Wyler (2003, p. 32-33) refere como consequência do processo de conquista a violência linguística sofrida por povos escravizados de origem africana trazidos ao Brasil após 1560, quando se proibiu a escravização de indígenas. Segundo Wyler (2003, p. 33): “A importação portuguesa seguia a política de variar o máximo possível a composição étnica e linguística de cada leva [de pessoas escravizadas], mantendo dispersos os grupos tribais nucleares de modo a evitar a unidade e insubmissão”. Ainda assim, foram adotadas línguas francas, como "o nagô e o iorubá (do grupo sudanês) na Bahia e o quimbundo ou conguês (do grupo banto) no norte e sul do Brasil" (WYLER, 2003, p. 34).

${ }^{8} \mathrm{O}$ wolof (ou uolofe), falado na África Ocidental, é considerado a primeira língua de parcelas relevantes da comunidade senegalesa que migrou ao Brasil. No Rio Grande do Sul, o perfil de migrante senegalês que veio entre 2013 e 2015, período do estudo de Uebel (2016) em que nos baseamos, é multilíngue. A população migrante pode dominar mais de uma das línguas regionais, como soninquê, serer, fulani, maninka e diola, além do wolof, e ser hábil, mas não necessariamente proficiente, no francês, espanhol, inglês e português. É de observar, porém, que o conhecimento desses idiomas e o bom nível de instrução desses migrantes não dispensa a tradução comunitária, pois as dificuldades do acesso efetivo à cidadania são culturais, sociais e simbólicas, muito mais que linguísticas.

${ }^{9}$ De acordo com Corbera Miranda e Mori (2020, p. 1), warao é “uma língua falada por uma população originária que ocupa uma ampla extensão da região do delta do rio Orenoco, Nordeste da República Bolivariana de Venezuela e norte das guianas ocidentais”. As autoras mencionam dados do censo venezuelano de 2011 que apontam a existência de 32.000 falantes da língua warao no país. Porém, dado o contato com a sociedade venezuelana e ações de grupos religiosos nas regiões ocupadas pelo povo warao, a língua está em situação de vulnerabilidade. Conforme dados da Agência da ONU para Refugiados (ACNUR), o deslocamento forçado por conta da crise humanitária na Venezuela, desde 2014, trouxe ao Brasil cerca de 5.799 refugiados e migrantes indígenas venezuelanos, dos quais $69 \%$ são da etnia warao.

${ }^{10}$ Conforme o Ipol, em dados atualizados em 15 de fevereiro de 2021 (http://ipol.org.br/lista-de-linguas-cooficiais-em-municipios-brasileiros/), 6 línguas dos processos de imigração alemã e italiana foram cooficializadas em 29 municípios. No Rio Grande do Sul, o talian foi cooficializado em 12 municípios gaúchos, o pomerano em 2 e o hunsriqueano em 2. 
O Rio Grande do Sul poderia ser considerado um Estado misto. Ou seja, para lá imigrou grande contingente da população européia durante o grande fluxo mas, além disso, possui uma continuidade de imigrantes sulamericanos. Essa migração sul-americana é que vai caracterizar os Estados que denominamos de "imigração internacional de fronteira" e que constitui a outra subdivisão do segundo subgrupo. O Rio Grande do Sul, que teve sempre grande número de estrangeiros em sua população, tem como nacionalidade principal, até 1950, os italianos (decrescendo de 32\% para 12,18\% no censo de 1970) e em terceiro lugar os alemães (que crescem de $11 \%$ para 16\% em 1940, decrescendo a seguir até 13,65\% em 1970, quando assumem o segundo lugar). Neste censo, o Uruguai que vinha se mantendo em segundo lugar de importância desde 1920, torna-se a nacionalidade mais importante nesse Estado com 19,40\%. O quarto lugar é assegurado a Polônia até 1950. Em 1970 devido a um aumento da proporção de portugueses, a Polônia apresenta-se em quinto lugar. A Rússia e Argentina alternam as próximas duas colocações através dos censos.

O município de Pelotas está localizado no entorno com números significativos de aldeias de povos tradicionais e comunidades quilombolas e com significativo número de pessoas que se autodeclararam indígenas e pretas no Censo de $2010^{11}$. Em região inicialmente habitada por povos originários (sobretudo charruas e guaranis, conforme o Instituto Socioambiental - ISA (2021) -, embora a etnia kaingang seja, também, muito presente no Rio Grande do Sul, conforme o Instituto Brasileiro de Geografia e Estatística - IBGE (2021), Pelotas alcançou seu apogeu econômico no século XIX impulsionado por contingentes escravizados submetidos a trabalhos nas charqueadas. Desde antes disso, porém, a cidade vem recebendo influxos platinos em decorrência de sua localização na faixa de fronteira ${ }^{12}$, condição que a insere na zona de influência do "portunhol" ${ }^{13}$, que ainda tende a ser estigmatizado como uma corruptela de ambos os idiomas envolvidos ${ }^{14}$. A fronteira sul do Brasil com o Uruguai, é de notar, caracteriza-se por intenso comércio, viabilizado pelos chamados free-shops, que acabaram por atrair migrações árabes e, mais recentemente, de comércios chineses.

Recentemente, Pelotas vem recebendo população de migração forçada, o que levou ao desenvolvimento de mecanismos de cooperação com os demais entes da federação na promoção de políticas públicas locais voltadas a pessoas imigrantes e em situação de refúgio, além de, em 2018, contar com coletivos de população imigrante/refugiada que se relacionavam com a prefeitura e a dispor de abrigo para o acolhimento de população imigrante/refugiada ${ }^{15}$. Por ser o terceiro município mais populoso do Estado do Rio Grande do Sul e o mais populoso da mesorregião da metade sul do Rio Grande do Sul ${ }^{16}$, acaba por concentrar parte significativa dos serviços públicos essenciais disponíveis na região, constituindo-se como polo médico, cultural e educacional, mas, também, de prestação jurisdicional para pessoas hipossuficientes. Em um contexto geográfico e demográfico como esse, a tradução comunitária é estimada como sendo de extrema relevância, e isso motivou a propositura deste projeto. No entanto, a prestação de serviços de tradução / interpretação comunitária não ocorreu da forma como, a princípio, esperava-se, o que pode estar relacionado a diversas variantes, entre as quais a dificuldade de implementar mudanças na prestação de serviços públicos em tempos de caos como o gerado por uma pandemia e mediante o emprego de ferramentas de comunicação remota. Por essa razão, foi na pesquisa e reformulação de textos científicos para disseminação de informações confiáveis à comunidade local, por meio de redes sociais, que a maior parte da equipe esteve concentrada.

\footnotetext{
${ }^{11}$ Conforme dados do Censo 2010 disponíveis no SIDRA (Tabela 3175), da população total de 328.275 residentes em Pelotas em 2010 , 483 pessoas se autodeclaram indígenas; 1.052, amarelas; 28.245, pardas, 35.049, pretas; 263.443, brancas. Embora o instituto não tenha questionado sobre a língua falada na residência, é possível levantar-se como hipótese que essa variedade étnica se correlacione com implicações linguísticas.

${ }^{12}$ Nos termos do art. $1^{\circ}$ da Lei 6.634, de 1979: "É considerada área indispensável à Segurança Nacional a faixa interna de 150 Km (cento e cinqüenta quilômetros) de largura, paralela à linha divisória terrestre do território nacional, que será designada como Faixa de Fronteira”.

${ }^{13}$ Utilizamos o termo sem atribuir um sentido unívoco, tampouco conotação pejorativa, cientes de que há múltiplos “portunhóis”, que variam conforme as situações de uso. De acordo com Sturza (2019, p. 103), pode-se identificar o "Portunhol Uruguaio, que uso aqui como renomeação do Fronterizo/Portugués del Uruguay; Portunhol como interação comunicativa; Portunhol como interlíngua e Portunhol Selvagem como recurso estético-linguístico. As ocorrências possibilitam desde já dizer que o Portunhol não é o mesmo em todas elas: embora tenham em comum o contato português e espanhol, os seus usos têm funções muito diferentes".
}

${ }^{14}$ Sturza (2019) retoma os estudos de Carvalho (2006, 2010 apud STURZA, 2019) para apontar a permanência de atitudes de desprestígio perante a variedade.

${ }^{15}$ Fonte: Munic IBGE 2018 - Cartograma 3 - Municípios com mecanismo de cooperação com os demais entes da federação na promoção e desenvolvimento das políticas públicas locais voltadas aos imigrantes e refugiados - 2018; Cartograma 4 - Municípios com associação e/ou coletivo da população imigrante/refugiados que se relacione com a prefeitura - 2018; Cartograma 5 - Municípios com abrigo para o acolhimento de imigrantes/refugiados - 2018

${ }^{16}$ Conforme consulta realizada em 27 de abril de 2021 no canal Cidades@ do IBGE: https://cidades.ibge.gov.br/brasil/rs/pelotas/panorama. 
Apesar de tudo isso, é possível afirmar que o projeto contribuiu para a valorização da diversidade linguística necessária para comunicar adequadamente orientações referentes à covid-19 e seus impactos pelo menos de duas formas: na busca de informações em diversas línguas e na conscientização a respeito das diferentes línguas para as quais a informação deveria ser traduzida de forma a atender as necessidades da comunidade. Além disso, implementou-se a tarefa de democratizar conteúdos científicos para a sua disseminação ao público amplo, para o que é necessário traduzir (dentro da própria língua materna) as formas de dizer típicas do registro científico, a fim de viabilizar a compreensão (e a consequente sensibilização para os cuidados) por parte de um público mais amplo e com menos conhecimentos específicos a respeito do assunto. Essa promoção da acessibilidade textual e terminológica, visando à democratização de conteúdos, conforma, sob a ótica das autoras e autor deste trabalho, um aspecto de extrema relevância para a educação linguística dos/as participantes. No entanto, por não envolver a transposição entre pares de línguas que norteiam a tradicional concepção de tradução, essa habilidade não foi referida pelos/as respondentes ao questionário enviado.

Considerado, pois, este projeto como uma forma de educação linguística e com base nos resultados obtidos pelo referido formulário, passa-se a apresentar, a seguir, método, resultados e discussão.

\section{MÉTODO}

Para conhecer melhor as 83 pessoas inscritas para participação no projeto "Tradução, mediação linguística e disseminação de informações à comunidade", elaborou-se um questionário para ser enviado via Google Forms. As respostas possibilitaram, primeiramente, fazer um mapeamento dos perfis disponíveis para atuação no projeto e, num segundo momento, realizar uma avaliação de seu andamento, de modo a possibilitar alterar os procedimentos durante as ações. As perguntas incluídas no formulário relacionavam-se com aspectos gerais (contato, nível de ensino, área) e os seguintes aspectos linguísticos: línguas conhecidas, nível linguístico e experiências com tradução. Por fim, foi perguntado sobre as motivações para a inscrição no projeto e a contribuição desse para aprimorar o conhecimento linguístico. Essas duas perguntas são de especial relevância para este estudo, pois o foco dessa discussão é justamente a educação linguística em atividades de tradução comunitária.

É de notar, porém, que, depois de três meses de realização do projeto, somente 30 participantes (36,1\%) preencheram o questionário e autorizaram o uso dos dados para a avaliação do projeto e para o presente estudo, apesar de o questionário ser sucinto e ter sido incentivada a participação. A seguir, são reportados os resultados, analisando-se os aspectos gerais da equipe de participantes e a contribuição deste projeto de tradução para a educação linguística.

\section{RESULTADOS E DISCUSSÃO}

No Gráfico 1, pode-se verificar que a maioria do voluntariado era proveniente de cursos de graduação, o que pode ser parcialmente explicado pela suspensão das aulas presenciais na universidade a partir do dia 13 de março de 2020, ao passo que, na pós-graduação, não se decidiu pela suspensão / prorrogação de prazos. Entretanto, as aulas passaram a ser ofertadas na modalidade remota e em módulo concentrado (com 12, em vez das costumeiras 17 semanas) em junho de 2020, visando a não atrasar concluintes de diferentes cursos. A partir desse momento, houve uma certa desmobilização na participação em atividades não obrigatórias. Ainda assim, manteve-se a disseminação de informações relacionadas à pandemia e a outros temas correlatos ${ }^{17}$ por meio de redes sociais até 31 de dezembro de 2020 (data final do projeto conforme planejamento inicial, haja vista que, quando da propositura deste projeto, não era possível estimar o prolongamento da pandemia e das restrições por ela provocadas por período superior a um ano).

\footnotetext{
${ }^{17}$ Houve uma preocupação em direcionar publicações do projeto para cuidados com saúde mental na pandemia, além de outros conteúdos, como dicas para a prática de alongamentos e exercícios, mesmo em confinamento. Ademais, levando em consideração que o Rio Grande do Sul é o Estado com maiores índices de suicídio no contexto brasileiro, foi realizada uma palestra com o Prof. Dr. Maurício Kunz, Professor de Psiquiatria da Universidade Federal do Rio Grande do Sul e Chefe do Setor de Psiquiatria do Hospital de Clínicas de Porto Alegre sobre prevenção ao suicídio, intitulada "Traduzir sinais; prevenir suicídios” (2020).
} 
Gráfico 1: Nível de ensino dos participantes durante o andamento do projeto

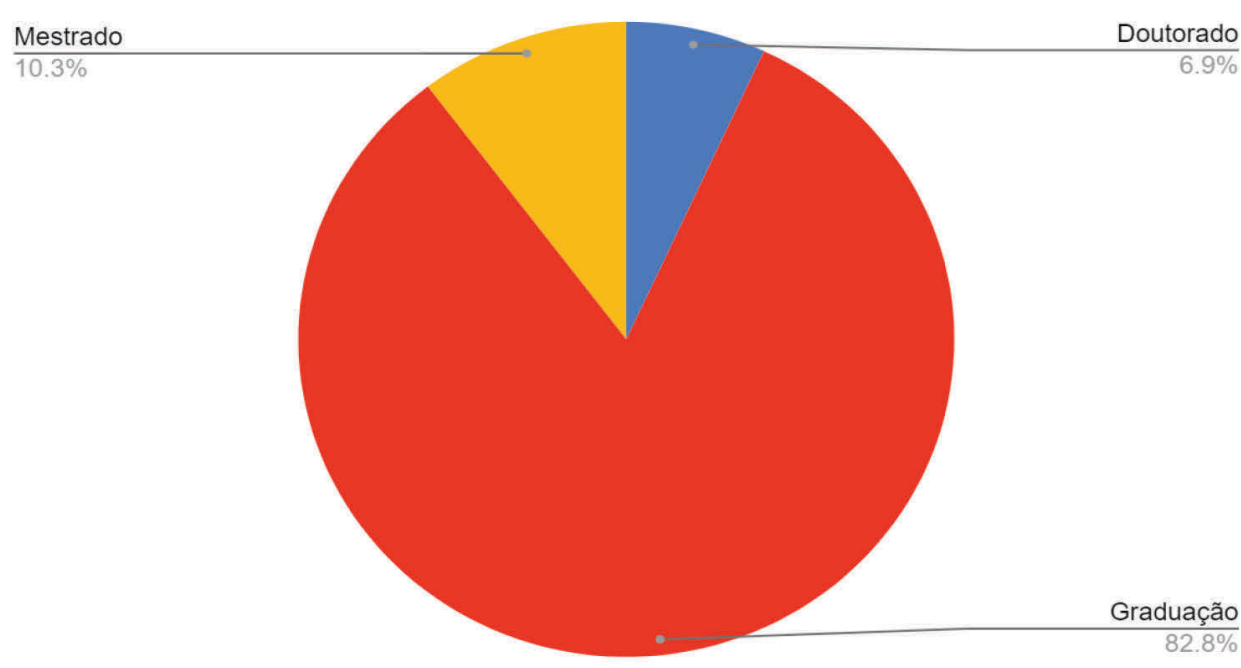

Fonte: elaborada pelos autores

O Gráfico 2 mostra os percentuais de participantes do projeto por área de conhecimento. Entende-se a predominância de estudantes da área de Letras em função de que as professoras/es responsáveis pelo projeto e por sua supervisão são também desta área. Em segundo lugar, estão alunos/as da área da Saúde, que provavelmente se sentiram motivados/as a entrar no projeto por conta da temática relacionada à covid-19. Dentre as pessoas que responderam ao questionário, 3 declararam ter o português como língua não materna e serem de nacionalidade estrangeira.

Gráfico 2: Área de estudo do curso durante o andamento do projeto

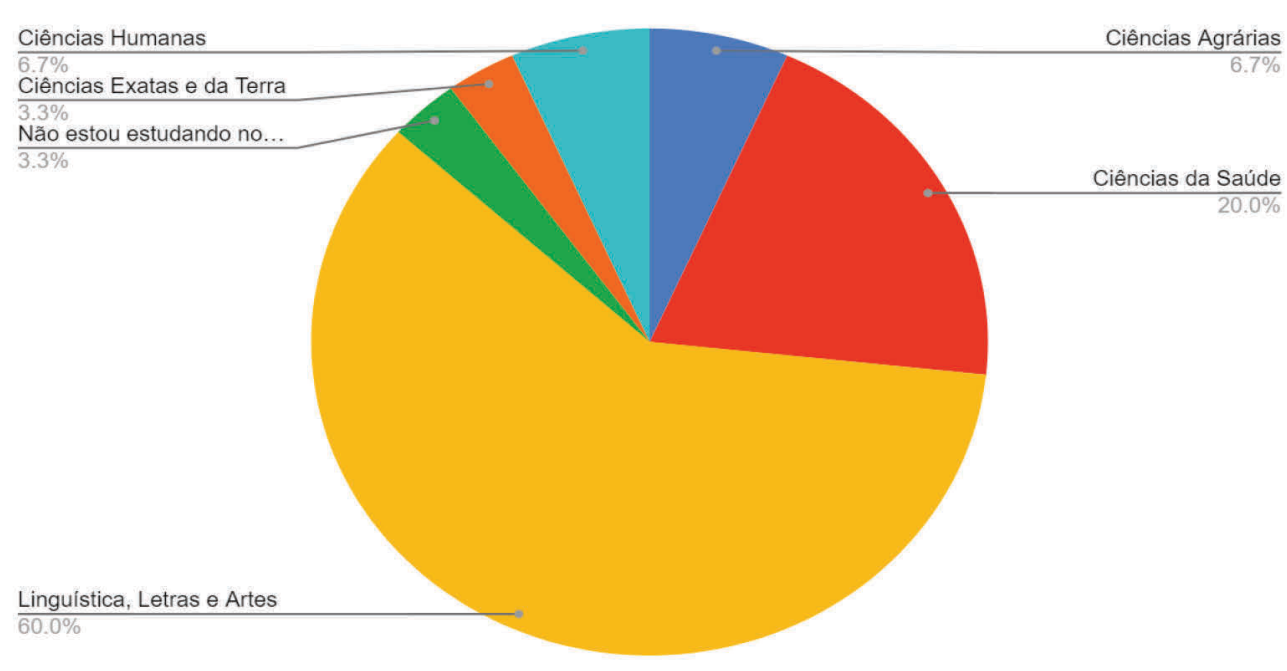

Fonte: elaborada pelos autores

O Gráfico 3 sintetiza o conhecimento de línguas além do português: alemão, espanhol, francês e inglês, selecionadas por serem as línguas que a UFPel oferece em nível de graduação nas licenciaturas duplas com o português, além dos bacharelados em tradução de inglês e espanhol e em redação e revisão de textos. Ressalta-se que os níveis foram autoatribuídos pelas pessoas participantes. Além disso, o questionário não permitia a segmentação por habilidades, de forma que tais respostas oferecem um panorama amplo, mas pouco detalhado, da proficiência linguística dos/as participantes. Com exceção do inglês, que contava com integrantes mais proficientes, todas as outras línguas tiveram o nível básico como o mais assinalado. As respostas para a pergunta sobre o conhecimento de outras línguas apontaram para conhecimento básico de italiano e libras, além de línguas de domínio menos frequente na nossa região, como o japonês e línguas africanas (não especificadas). As pessoas que indicaram libras como língua de 
atuação eram estudantes de licenciatura em Letras, o que nos permite inferir que seu conhecimento da língua veio da disciplina presente nos currículos de cursos de formação de educação especial, de fonoaudiologia e de licenciaturas, de acordo com a Lei ${ }^{\circ}$ 10.436 (BRASIL, 2002).

Gráfico 3: Conhecimento de línguas autodeclarado durante o andamento do projeto

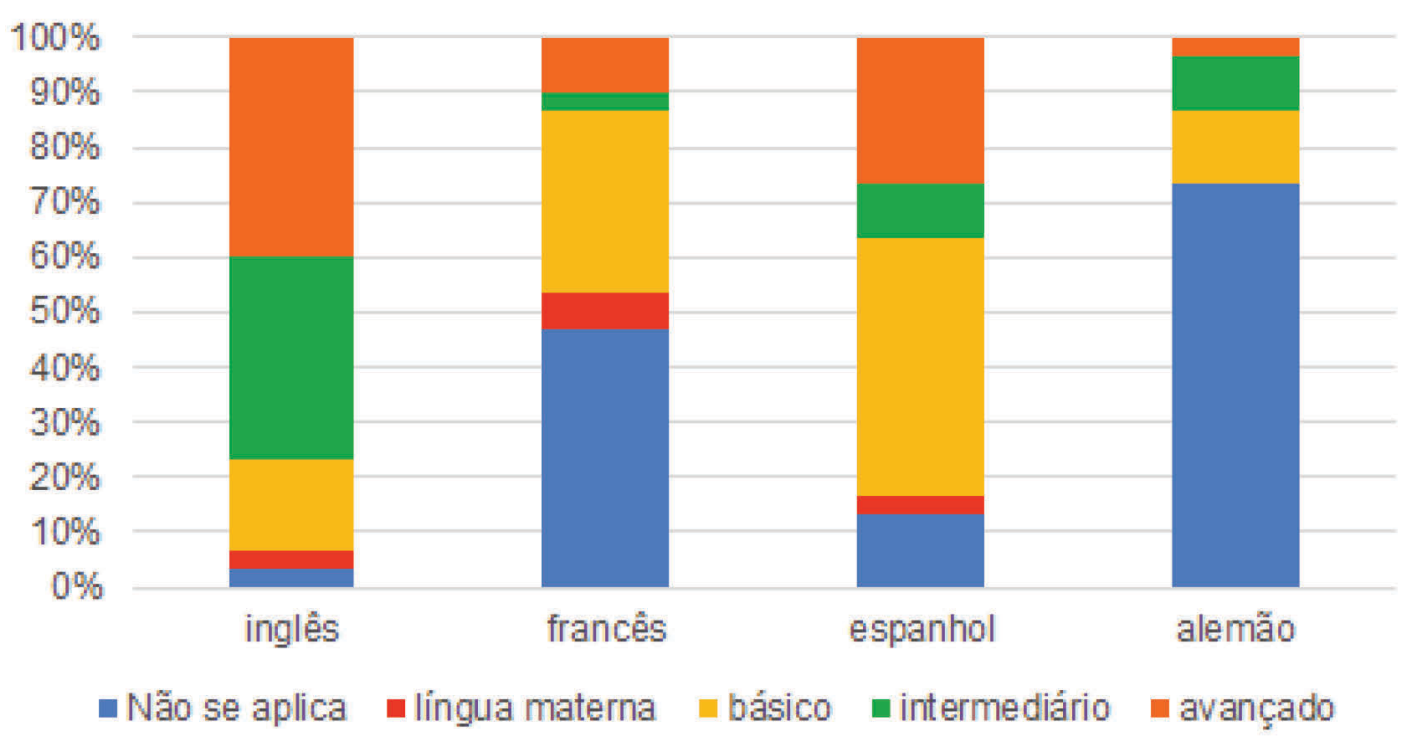

Fonte: elaborada pelos autores

Os/as participantes tiveram motivações diversas para ingressarem no projeto. A vontade de prestar voluntariado chama atenção nas respostas: "ajudar pessoas que estivessem tendo problema com a comunicação"; "ajudar a inserir imigrantes e refugiados na sociedade brasileira”. É de destacar, portanto, que integrantes do projeto tinham como intenção primordial ajudar comunidades como a surda, a de migração forçada ou voluntária, ou mesmo pessoas nascidas no território brasileiro, mas que, pelas configurações demográficas / linguísticas locais, não têm pleno domínio da língua portuguesa. Essas intenções têm relação com o objetivo de prestar mediação linguística e cultural à população falante de línguas minorizadas e/ou em situação de vulnerabilidade social, migração e refúgio. Os/as participantes também buscaram disseminar informações confiáveis e manter a comunidade informada sobre a pandemia, preocupando-se com a qualidade e veracidade das informações veiculadas na mídia e redes sociais às quais a população tem acesso.

Motivações relacionadas à educação linguística (BAGNO; RANGEL, 2005) apareceram em 12 das 30 respostas, ou seja, os/as participantes afirmaram terem ingressado no projeto com o intuito de aperfeiçoarem os seus conhecimentos: "acrescentar conhecimento e crescer como um profissional de tradução"; "praticar a língua estrangeira"; "a maior motivação é a troca do conhecimento"; "aprender sobre o trabalho de tradução textual". Dessa forma, é possível verificar tanto motivações de solidariedade e advindas do contexto epidemiológico excepcional quanto a busca pelo desenvolvimento de habilidades linguísticas e competência tradutória (ALBIR, 2005) como atributos desejáveis à formação profissional também em estudantes de outros cursos que não os de Letras. Houve, também, participantes que afirmaram buscar o projeto pela possibilidade de trabalho coletivo e interdisciplinar e pela promoção de trocas e interações com outras pessoas em um momento em que as formas de convivência e as interações interpessoais passavam por grandes mudanças.

Em relação às contribuições do projeto no que diz respeito ao conhecimento de línguas dos participantes, foi possível constatar, nas respostas, uma gama de possibilidades, tais como: (1) melhora na escrita em português e (2) no conhecimento de outras línguas, principalmente no que diz respeito ao vocabulário, (3) aprimoramento de técnicas e da experiência de tradução, (4) melhora nas habilidades de leitura e escrita, (5) desenvolvimento de letramentos acadêmicos e/ou informacionais, e, por fim, (6) importância da interação e do feedback. Abaixo, desenvolvem-se as possibilidades apontadas pelo grupo participante. 
O grupo respondente às questões apresentadas afirmou que o projeto foi útil em relação à melhora na escrita em português - algo apontado tanto por pessoas de nacionalidade estrangeira quanto por falantes nativos - e no conhecimento de outras línguas, especialmente em função da possibilidade de contato com textos em diferentes línguas. Isso, inclusive, pode ser observado em algumas respostas diretamente relacionadas ao aprendizado de outras línguas: "me animei e comecei a estudar italiano no Duolingo", "já estou pensando em aprender russo". Além disso, a publicação de textos em redes sociais e para um público amplo impulsionou a autoexigência por precisão linguística: "tenho exercitado bastante a revisão dos textos traduzidos". Outro aspecto a se destacar nas respostas é a importância dada à terminologia e à aquisição de vocabulário relacionado à covid-19, o que por vezes demandou pesquisas, leituras e (re)formulação de mensagens em área do conhecimento diversa de seu curso de origem, a desacomodação da zona de conforto e a demonstração de importância da "precisão dos termos médicos mais técnicos" na comunicação científica.

Estreitamente relacionada à questão do vocabulário, também foram apresentadas perguntas sobre a experiência em tradução. Como afirmado anteriormente, muitas participações provinham dos cursos de Letras, tanto licenciaturas quanto bacharelados, sendo que, pela conformação curricular atual da UFPel, apenas esses têm disciplinas de tradução com teorias e exercícios para aquisição da competência tradutória ao longo da sua formação. Conforme uma resposta recebida, "[o projeto] tem me feito pensar sobre várias questões tradutórias e desafios enfrentados pelo tradutor: tempo de trabalho, ferramentas terminológicas e tecnológicas, divulgação do trabalho de tradução, etc". Dessa forma, o projeto ofereceu a oportunidade de atuação como tradutor(a) em um momento de grande necessidade e premência, possibilitando à equipe participante, inclusive às pessoas que nunca a tinham vivenciado, experiências tradutórias reais, permitindo vislumbrar a realidade da profissão e a importância da autonomia na busca por aprimoramento profissional a partir das situações vivenciadas na prática.

Outra contribuição do projeto foi o desenvolvimento de letramentos informacionais e acadêmicos. Em primeiro lugar, a busca por informações confiáveis foi mencionada por diversos/as participantes; algumas respostas ao formulário claramente apontavam para a importância dessa habilidade em um momento em que se vive também uma infodemia ${ }^{18}$. A busca por boas fontes de informação foi também ressaltada, tendo em vista o objetivo do projeto de fornecer tais informações à comunidade, o que implica uma atitude ética na forma como se lidam com os discursos aos quais se tem acesso e aqueles que são escolhidos para se fazer reverberar. Dessa forma, as pessoas participantes necessitaram saber como julgar a confiabilidade dos materiais disponíveis sobre a covid-19, o que envolve a habilidade de identificar certas mensagens como falsas ou "desinfodêmicas", conforme Possetti e Bontcheva (2020), em manual disponibilizado no site da Unesco, a fim de prevenir a propagação de falsidades sobre a pandemia e seus impactos. Em outras palavras, implica a habilidade de distinguir informações científicas das construções narrativas que mesclam terminologia e características do texto científico com opiniões pessoais ou baseadas em linguagem fortemente emotiva (como, com frequência, ocorre em relatos falsos) ou informações propositadamente mentirosas, incompletas ou descontextualizadas (como frequentemente o são os memes virais). Além disso, os/as participantes afirmaram que o projeto permitiu maior contato com textos de revistas científicas, como artigos.

De forma relacionada, há, também, o relato de melhora nas habilidades de leitura e escrita, de que se pode concluir que a exposição a diferentes e/ou novos gêneros discursivos (artigos científicos, textos de divulgação científica, decretos governamentais e discursos de autoridades etc.) teve um impacto nas práticas de leitura, principalmente de textos em língua estrangeira. Conforme uma das respostas recebidas, "é muito bom para se acostumar a ler artigos, que têm uma linguagem mais técnica e, portanto, são mais cansativos, e assim apenas o hábito torna mais simples o contato com esses textos”. Portanto, a situação enfrentada pelo grupo participante na pandemia e no projeto possibilitou a incorporação de outros gêneros ao seu repertório de forma significativa. Como exemplo, uma pessoa respondeu: "estou conseguindo usar de forma prática a leitura de artigos relacionados ao meu curso, aprimorando o meu aprendizado". De maneira mais específica, houve, também, uma menção à importância da linguagem escrita formal e da ortografia correta. É possível especular que os/as participantes possam ter valorizado esses aspectos em decorrência da

\footnotetext{
${ }^{18}$ A Organização Pan-Americana da Saúde (2020) define a infodemia como "um grande aumento no volume de informações associadas a um assunto específico, que podem se multiplicar exponencialmente em pouco tempo devido a um evento específico, como a pandemia atual. Nessa situação, surgem rumores e desinformação, além da manipulação de informações com intenção duvidosa. Na era da informação, esse fenômeno é amplificado pelas redes sociais e se alastra mais rapidamente, como um vírus".
} 
publicação dos textos traduzidos em canais de comunicação do projeto no perfil do Facebook e site do projeto. Assim, ter interlocutores/as reais em uma situação de comunicação concreta levou a que alunos/as se preocupassem mais com aspectos formais da linguagem escrita.

Por fim, algumas pessoas mencionaram a importância das trocas e do feedback na construção do conhecimento relativo ao projeto - "na troca de conhecimento com os outros (quando mando um resumo, o feedback que se faz depois)" - o que pode ter sido particularmente importante em um momento de bruscas alterações nas formas de contato, interação e aprendizagem, provocadas pela necessidade de distanciamento social.

\section{CONSIDERAÇÕES FINAIS}

Este artigo buscou relatar a experiência de um projeto desenvolvido na UFPel, cujo objetivo principal era ofertar atividades complementares visando à tradução para a comunidade (especialmente à comunidade local), mas que acabou por contribuir para a educação linguística dos/as participantes, conforme constatou-se ao longo de seu desenvolvimento e se confirmou por meio de questionário. Esse consistiu em formulário (Google forms) elaborado pelo/as autor/as deste texto, atuantes na supervisão de equipes vinculadas ao projeto, e enviado às pessoas participantes. Verificou-se nas respostas aos questionários que a participação neste projeto possibilitou a conscientização a respeito da diversidade linguística, em especial quanto à diversidade de línguas faladas na região (e que impõem a necessidade de atendimento multilíngue nos serviços públicos e de atendimento ao público). Constatou-se, portanto, uma sensibilização quanto à necessidade de acesso à informação por populações em situação de migração, seja voluntária ou forçada (especialmente falantes de espanhol), de comunidades internas falantes de línguas minorizadas (como línguas de imigração alemã, bastante presentes em município do entorno ${ }^{19}$ ) e nas línguas dos povos originários presentes na região, para além das pessoas com deficiência, tais como pessoas surdas e ensurdecidas ${ }^{20}$ e pessoas cegas ${ }^{21}$ e de baixa visão. Além disso, evidenciou-se a importância do conhecimento de línguas (estrangeiras) para o acesso a e disseminação de informações a respeito da covid-19 que não estariam disponíveis em português de outra maneira. Trata-se, aqui, de um dos aspectos mais elementares relacionados ao conhecimento linguístico: o de possibilitar a descoberta de outros conteúdos e pontos de vista, o que, especialmente no período da pandemia, tem sido crucial.

Conforme apontamos anteriormente, foi possível constatar um cuidado dos/as participantes na seleção de informações confiáveis, dado o impacto da sua divulgação na comunidade. Além disso, houve contato com gêneros discursivos novos, tanto na recepção quanto na produção, bem como trabalhou-se com a capacidade de transposição de conteúdo em linguagem científica para um público leigo, contribuindo para o desenvolvimento de letramentos informacionais e acadêmicos ou de tradução para a acessibilidade. Acredita-se que, nesse sentido, o projeto cumpriu uma função social importante, pois permitiu ao grupo atuante concluir, ainda que com palavras e modos de expressar outros, que "letrar não é simplesmente 'ensinar a ler e a escrever', mas criar condições para que o indivíduo ou o grupo possa exercer a leitura e a escrita de maneira a se inserir do modo mais pleno e participativo na sociedade tipicamente letrada que é a nossa” (BAGNO; RANGEL, 2005, p. 69).

\footnotetext{
${ }^{19}$ São Lourenço do Sul e Canguçu, dois municípios limítrofes a Pelotas, têm o pomerano como língua cooficial do Município, conforme levantamento do Ipol (2021).
}

${ }^{20}$ Conforme a Pesquisa Nacional de Saúde, levada a campo pelo IBGE em 2013, no total da população brasileira, "0,9\% adquiriu a deficiência auditiva por doença ou acidente e $0,2 \%$ a possuía desde o nascimento" (f. 27). A tradução acessível voltada a pessoas com surdez adquirida e que com frequência não conhecem libras é ainda pouco estudada no Brasil. É de notar, também, que, embora uma Pesquisa Nacional de Saúde tenha sido empreendida em 2019, os módulos referentes a pessoas com deficiência, plano de saúde, e exposição a violência "passaram por reformulações”, conforme explica a publicação que traz nos créditos os Ministros da Saúde, Eduardo Pazuello, e da Economia, Paulo Guedes, entre outros integrantes do governo que influenciaram na definição de questões a serem investigadas (IBGE, 2019, f. 11). Não foram encontrados dados oficiais mais recentes sobre esses três aspectos "reformulados".

${ }^{21}$ Segundo a Pesquisa Nacional de Saúde (IBGE, 2013), a deficiência visual é a mais prevalente na população brasileira. Sem distinguir entre pessoas cegas e com baixa visão, a pesquisa apontou que $3,6 \%$ da população brasileira apresenta "cegueira de ambos os olhos, cegueira de um olho e visão reduzida do outro, cegueira de um olho e visão normal do outro ou baixa visão de ambos os olhos” (f. 28), das quais 0,4\% convivem com a deficiência desde o nascimento. Considerando-se que essa deficiência abarca 11,5\% da população com 60 anos de idade ou mais (justamente o grupo considerado de risco por infecção por covid-19), merecem estudos futuros as formas como a informação para o cuidado e a prevenção circulou entre esses grupos durante a pandemia. 
Embora o projeto não tenha implementado ações que se possam caracterizar como de tradução comunitária de fato, como discutido ao longo do artigo, é possível afirmar que uma das suas contribuições mais evidentes refere-se às potencialidades da tradução para a educação linguística. Como Romanelli (2009) defende, a tradução seria considerada a quinta habilidade linguística, devendo ser desenvolvida em língua estrangeira juntamente com a compreensão auditiva e leitora e a produção oral e escrita. O uso da tradução na educação linguística contrapõe teorias de aprendizagem de segunda língua pautadas no monolinguismo e, segundo o autor, se usada de forma adequada e parcimoniosa, motiva os/as estudantes, favorece o desenvolvimento da autonomia e da competência metalinguística.

Ademais, a participação em um projeto que visa à aplicação das habilidades linguísticas em ações concretas baseadas em textos reais e visando ao benefício da sociedade, fez com que os/as alunos/as refletissem e pesquisassem sobre essa comunidade à qual a sua atividade se destinava. Com isso, promoveu-se a cidadania e um olhar mais cuidadoso à sociedade e às suas vulnerabilidades várias, que são sociais, jurídicas e econômicas, mas, também, linguísticas e cognitivas, e que, portanto, demandam esforços tradutórios, seja entre línguas, seja dentro de uma mesma língua. A partir da conscientização da diversidade de línguas e culturas existentes na região, espera-se que este projeto tenha motivado estudantes a refletir sobre a comunicação voltada às parcelas mais vulneráveis da sociedade monolíngue e sobre formas de democratizar o acesso a conhecimentos que deveriam ser de todos/as. Busca-se, portanto, o reconhecimento do direito a compreender e a ser compreendido/a, de comunicar e a ser ouvido/a como um direito fundamental e, nesses termos, extensível à totalidade das pessoas, sejam quais sejam suas características demográficas e/ou de linguagem. Em outras palavras, busca-se que a universidade amplie sua oferta de atividades extensionistas e planeje novas formas de comunicar, de fazer pesquisa e de reassumir o protagonismo na disseminação de informações e cultura à comunidade, para muito além dos conteúdos relacionados à saúde e mesmo deste contexto de pandemia. Como alerta Boaventura de Sousa Santos (2020, p. 29), muito da crise atual deve-se à "proletarização produtivista dos professores e a conversão dos estudantes em consumidores de serviços universitários", que tem início quando a universidade insere-se na lógica de mercado e nos critérios de rentabilidade do "capital social”.

Portanto, tão pronto haja condições de segurança epidemiológica e de capacitação de equipes para a implementação efetiva da oferta de serviços de tradução comunitária, pretende-se retomar este projeto e com ainda mais ânimo. Para a necessária capacitação de equipes para atuação em uma área da tradução de interesse relativamente novo no Brasil, é fundamental a atuação interdisciplinar e interinstitucional. Com relação a esse aspecto, refere-se à atuação decidida do grupo Mobilang, que, agrupando pessoas de diversas regiões geográficas, com diferentes backgrounds e usuárias de distintas línguas, tem atuado em prol da formação de um banco de intérpretes, para o que começou a oferecer um curso gratuito de formação de pessoas habilitadas a atuar com a interpretação comunitária. Um dos objetivos desse banco é o de promover o acesso à justiça e às demandas da comunidade migrante e, em especial, em situação de refúgio, assistida pela Defensoria Pública da União, instituição com a qual o Mobilang tem parceria firmada. Nesse interregno, espera-se que possa avançar na tramitação o Projeto de Lei no 5.182/2020 (SENADO FEDERAL, 2020), de iniciativa do senador Paulo Paim, que busca instituir a obrigatoriedade de tradutores e intérpretes comunitários em instituições públicas.

\section{REFERÊNCIAS}

ACNUR. Dados sobre refúgio no Brasil. ACNUR, 2021. Disponível em: https://www.acnur.org/portugues/dados-sobrerefugio/dados-sobre-refugio-no-brasil. Acesso em: 27 abr. 2021.

ACNUR. Relatório global do ACNUR revela deslocamento forçado de 1\% da humanidade. ACNUR, 2020. Disponível em: https://www.acnur.org/portugues/2020/06/18/relatorio-global-do-acnur-revela-deslocamento-forcado-de-1-da-humanidade. Acesso em: 27 abr. 2021.

ACNUR. Atuação do ACNUR junto às redes locais em apoio à população indígena warao no sudeste e sul do Brasil: boas práticas e lições aprendidas. ACNUR, 2021. Disponível em: https://www.acnur.org/portugues/wpcontent/uploads/2021/05/210531_ACNUR_RelatorioWarao.pdf. Acesso em: 14 nov. 2021. 
ALBIR, A. H. A aquisição da competência tradutória: aspectos teóricos e didáticos. In: PAGANO, A., MAGALHÃES, C., ALVES, F. (org.). Competência em tradução: cognição e discurso. Belo Horizonte: Editora UFMG, 2005. p. 19-57.

BAGNO, M.; RANGEL, E. de O. Tarefas da educação lingüística no Brasil. Rev. bras. linguist. apl., [s.l.], v. 5, n. 1, p. 63-81, 2005. Disponível em: https://www.scielo.br/j/rbla/a/LdCCsV35tZzGymcnq8DcW5p/?lang=pt. Acesso em: 27 abr. 2021.

BRASIL. Lei $n^{\circ}$ 10436, de 24 de abril de 2002, que "dispõe sobre a Língua Brasileira de Sinais - Libras e dá outras providências". Disponível em: http://www.planalto.gov.br/ccivil_03/leis/2002/110436.htm. Acesso em: 27 abr. 2021.

BRASIL. Lei n $n^{\circ}$ 6.634, de 2 de maio de 1979, que "dispõe sobre a Faixa de Fronteira, altera o Decreto-lei no 1.135 , de 3 de dezembro de 1970, e dá outras providências". Disponível em: http://www.planalto.gov.br/ccivil_03/leis/16634.htm. Acesso em: 27 abr. 2021.

COPE, B.; KALANTZIS, M. (ed.). Multiliteracies: literacy learning and the design of social futures. New York: Taylor and Francis Group, 2000.

CORBERA MORI, A.; MIRANDA, C. C. O contato warao-espanhol: considerações sobre o processo de aculturação lexical da língua nativa do delta do Orenoco. LIAMES: Línguas Indígenas Americanas, Campinas - SP, v. 20, n. 00, p. e020010, 2020. Disponível em: https://periodicos.sbu.unicamp.br/ojs/index.php/liames/article/view/8661196. Acesso em: 14 nov. 2021.

IBGE (Instituto Brasileiro de Geografia e Estatística). Perfil dos municípios brasileiros: 2018. IBGE, Coordenação de População e Indicadores Sociais. Rio de Janeiro: IBGE, 2019.

IBGE. O Brasil indigena (folder). 2021 IBGE, Disponível em: https://indigenas.ibge.gov.br/images/pdf/indigenas/folder_indigenas_web.pdf. Acesso em: 27 abr. 2021.

IBGE. Pesquisa nacional de saúde - 2019: atenção primária à saúde e informações antropométricas. IBGE, Coordenação de Trabalho e Rendimento. Rio de Janeiro: IBGE, 2020.

IBGE. Pesquisa nacional de saúde - 2013: ciclos de vida - Brasil e grandes regiões. IBGE, Coordenação de Trabalho e Rendimento. Rio de Janeiro: IBGE, 2015.

IBGE. Os indígenas no Censo Demográfico 2010: primeiras considerações com base no quesito cor ou raça. IBGE, Diretoria de Pesquisas. Rio de Janeiro: $2012 . \quad$ Disponível em: https://indigenas.ibge.gov.br/images/indigenas/estudos/indigena_censo2010.pdf. Acesso em: 27 abr. 2021.

IPOL. Lista de línguas cooficiais em municípios brasileiros. IPOL, 2021. Disponível em: http://ipol.org.br/lista-de-linguascooficiais-em-municipios-brasileiros/. Acesso em: 27 mar. 2021.

ISA. Quadro geral dos povos. ISA, 2021. Disponível em: https://pib.socioambiental.org/pt/Quadro_Geral_dos_Povos. Acesso em: 30 abr. 2021.

JAKOBSON, R. Aspectos linguísticos da tradução. In: JAKOBSON, R. Linguística e comunicação. Tradução de Izidoro Blikstein e José Paulo Paes. 14. ed. São Paulo: Cultrix, 1991.

LEA, M. Academic Literacies: a pedagogy for course design. Studies in Higher Education, [s.l.], v. 29, n. 6, p. 739-756, 2004.

LEA, M. R.; STREET, B. V. The “academic literacies” model: theory and applications. Theory into practice, [s.l.], v. 45, n. 4, p. 368$377,2006$. 
LEVY, M. S. F. O papel da migração internacional na evolução da população brasileira (1872 a 1972). Revista de Saúde Pública, São Paulo, Universidade de São Paulo (USP), Faculdade de Saúde Pública, v. 8, p. 49-90, jun. 1974.

MOBILANG. 2021. Disponível em: http://www.mobilang.unb.br. Acesso em: 30 abr. 2021.

OPAS. Entenda a infodemia e a desinformação na luta contra a COVID-19. Iris, 2020. Disponível em: https://iris.paho.org/handle/10665.2/52054?locale-attribute=pt. Acesso em 29 abr. 2021.

ORIGUELA, D. A. Interpretação comunitária, direitos humanos e assistência social: proposta de política pública no contexto brasileiro. TradTerm, São Paulo, v. 23, p. 225-240, set./2014.

POSETTI, J.; BONTCHEVA, K. Desinfodemic: deciphering COVID-19 disinformation. Unesco, 2020. Disponível em: https://en.unesco.org/sites/default/files/disinfodemic_deciphering_covid19_disinformation.pdfAcesso em: 27 mar. 2021.

RECUERO, R.; SOARES, F.; ZAGO, G. Polarização, Hiperpartidarismo e Câmaras de Eco: como circula a desinformação sobre covid-19 no twitter. Revista Contracampo, [s.l.], v. 40, n. 1, p. 0-0, 30 abr. 2021. Disponível em: https://periodicos.uff.br/contracampo/article/view/45611. Acesso em: 28 out. 2021

ROMANELLI, S. O uso da tradução no ensino-aprendizagem das línguas estrangeiras. Revista Horizontes de Linguística Aplicada, [s.l.], v. 8, n. 2, p. 200-219, 2009.

RUSSEL, D. Letramento acadêmico: leitura e escrita na universidade. [Entrevista concedida a Flávia Brocchetto Ramos e Vânia Marta Espeiorin]. Conjecturas, Caxias do Sul, v. 14, n. 2, p. 241-247, 2009.

SANTOS, B. de S. A cruel pedagogia do vírus. São Paulo: Boitempo, 2020.

SENADO FEDERAL. Projeto de Lei $n^{\circ}$ 5182, de 2020. Disponível em: https://www25.senado.leg.br/web/atividade/materias//materia/145443. Acesso em: 30 abr. 2021.

SOARES, F. B.; RECUERO, R.; VOLCAN, T.; FAGUNDES, G.; SODRÉ, G. Desinformação sobre o Covid-19 no WhatsApp: a pandemia enquadrada como debate político. Ciência da Informação em Revista, [s. 1.], v. 8, n. 1, p. 74-94, 2021. DOI: 10.28998/cirev.2021v8n1e. Disponível em: https:/www.seer.ufal.br/index.php/cir/article/view/11246. Acesso em: 28 out. 2021.

SPOLSKY, B. Language Management. New York: Cambridge University Press, 2009.

STURZA, E. 'Portunhol': língua, história e política. Gragoatá, [s.l.], v. 24, n. 48, p. 95-116, 2019.

TRANSLATORS WITHOUT BORDERS [TWB]. TWB glossary for COVID-19, 2020. Disponível em: https://translatorswithoutborders.org/twb-glossary-for-covid-19. Acesso em: 27 abr. 2021.

TRADUZIR sinais, prevenir suicídios - palestra com dr. Maurício Kunz. [S.l]. Tradução comunitária, 2020. 1 vídeo (01h41min). Disponível em: https://www.youtube.com/watch?v=RCKxylePP_4. Acesso em: 30 jan. 2022.

UEBEL, R. R. G. Panorama e perfil da imigração senegalesa no Rio Grande do Sul no início do século XXI. Boletim Geográfico do Rio Grande do Sul, Porto Alegre, n. 28, p. 56-77, set. 2016. 
UFPel. Tradução, mediação linguística e disseminação de informações à comunidade, 2020. Disponível em: https://institucional.ufpel.edu.br/projetos/id/u2574. Acesso em 30 jan. 2022.

UFPel. Boletins diários do Comitê UFPel Covid-19. Disponíveis em: https://wp.ufpel.edu.br/covid19/boletim-diario/. Acesso em: 27 abr. 2021.

UFPel. Política Linguística da UFPel. Resolução no 01/2020 do COCEPE, de 20 de fevereiro de 2020. Disponível em: https://wp.ufpel.edu.br/scs/cocepe/resolucoes/2020-2/. Acesso em: 14 abr. 2020.

WYLER, L. Língua, poetas e bacharéis: uma crônica da tradução no Brasil. Rio de Janeiro: Rocco, 2003.

\section{(c) (1) $(9$}

Recebido em 02/05/2021. Aceito em 17/11/2021. 


\section{ANEXO A - INSTRUÇÕES PARA OS PARTICIPANTES DO PROJETO}

1) Vamos evitar conteúdo de opinião, sites de notícias e matérias jornalísticas (salvo quando seja esta a única fonte em que circulou a notícia); (2) Vamos priorizar conteúdo de revistas científicas com credibilidade no campo, de instituições que estão atuando no combate à pandemia e divulgação de normas que possam instruir ou aprimorar procedimentos na nossa comunidade; (3) O conteúdo deve ser sintético, enviado no corpo do e-mail (não anexo), com o link para conferência do material, e seguindo a seguinte estrutura sempre:

$$
\text { TÍTULO - INFORMATIVO, CURTO E EM CAIXA ALTA }
$$

Conteúdo em português (exceções serão admitidas apenas quando voltadas a comunidades de migrantes e mesmo neste caso deve observar as demais regras) preferentemente em um parágrafo ou o mais sintético possível. Usar linguagem compreensível ao público amplo, dar preferência a frases na ordem direta. Explicar que novidades traz a pesquisa e como ela pode impactar a vida da nossa comunidade (benefícios ou malefícios). Se necessário, encerrar com um alerta ou sugestões.

Fonte da publicação (acompanhada do link para conferência):

Data da publicação:

Autores:

Pesquisa e redação feita por: Nome de vocês - Curso -

Obs.: Caso seja inviável informar link (por ser matéria de conteúdo fechado), enviá-la como anexo (apenas nesta hipótese!) para conferência e informar, ao final da postagem, dados da publicação conforme normas técnicas. 